beneficial, since it protects against rhesus isoimmunisation. ${ }^{21}$ Possibly other immune processes are protective and beneficial in pregnancy. Furthermore, while the chances seem high that any immune disturbance has a primary place in the chain of events, possibly immunological processes are also implicated at some other point-for example, after tissue damage has been caused. Finally, we must remember that, as in diabetes, all cases of PET may not be caused in the same way.

${ }^{1}$ Gant, N F, et al, American fournal of Obstetrics and Gynecology, 1971, 111, 555.

${ }^{2}$ Gant, N F, et al, Endocrinology, p 1026. International Congress Series No 237, Amsterdam, Excerpta Medica, 1972.

${ }^{3}$ Gant, N F, et al, Fournal of Clinical Investigation, 1973, 52, 2682.

4 Gant, N F, et al, American fournal of Obstetrics and Gynecology, 1974, 120, 1.

${ }^{5}$ Gant, N F, et al, Obstetrics and Gynecology, 1976, 47, 319.

6 Sophian, J, Pregnancy Nephropathy. London. Butterworths, 1972.

7 Lancet, 1975, 2, 487.

${ }^{8}$ Brosens, I, Robertson, W B, and Dixon, H G, fournal of Pathology and Bacteriology, 1976, 93, 569.

${ }^{9}$ Brosens, I, Robertson, W B, and Dixon, H G, Obstetrics and Gynecology Annual, ed R M Wynn, p 177. New York, Appleton-Century-Crofts, 1972.

10 Robertson, W B, Brosens, I A, and Dixon, H G, American fournal of Obstetrics and Gynecology, 1973, 117, 294.

11 Paterson, W G, and Grant, K A, Obstetrical and Gynecological Survey, $1975,30,715$.

12 Paterson, W G, British fournal of Obstetrics and Gynaecology, 1976, 83, 336.

13 Mathews, J D, Whittingham, S, and Mackay, I R, Lancet, 2, 1423.

14 Peters, D K, and Lachmann, P J, Lancet, 1974, 1, 58.

15 Stevenson, A C, et al, Lancet, 1971, 2, 1286.

${ }_{16}$ Petrucco, O M, et al, British Medical fournal, 1974, 1, 473.

17 Tribe, C R, Smart, G E, and Mackenzie, J C, British Medical fournal, 1974, 2, 335.

18 Thomson, N C, et al, British Medical fournal, 1976, 1, 1307.

${ }^{19}$ Humphrey, J H, British Medical Bulletin, 1976, 32, 182.

${ }^{20}$ Petrucco, O M, British fournal of Obstetrics and Gynaecology, 1976, 83, 245.

${ }^{21}$ Woodrow, J C, and Donohoe, W T A, British Medical fournal, 1968, 4, 139.

\section{Symptomatic care in motor neurone disease}

Motor neurone disease (MND) is an uncommon but devastating disease characterised by progressive wasting and weakness of the arms and spastic weakness of the legs, associated with progressive dysarthria and increasing difficulty in swallowing and breathing. ${ }^{1}$ Two-thirds of those affected are men, many in the prime of life. ${ }^{2}$ Guanidine may modify the course of the disease, ${ }^{3}$ but no generally satisfactory treatment is available. Well-documented spontaneous remission is rare, and, though some patients have lived for more than 15 years after diagnosis, most die within three. ${ }^{4}$

The thought processes are unimpaired and the patient is fully aware of his increasing disabilities. The continuing deterioration lowers the morale of the patient, his family, and those caring for him. ${ }^{5}$ Doctors will therefore welcome a recent article about the symptomatic care of patients with MND. ${ }^{6}$ Smith and Norris emphasised that, despite his inability to treat the primary disease, the physician can treat symptomatically many of the problems. Help must, however, be given quickly: many patients spend their last years waiting for one thing or another which arrives too late to be of value. ${ }^{7}$ Close co-operation is needed among neurologist, general practitioner, and medical social worker.

Difficulties in getting about are best met by providing an electric wheelchair early. Patients should use this to avoid fatigue, reserving their limited strength for occasions when a wheelchair is impracticable. Physiotherapy helps to reduce disuse atrophy and to prevent contractions. Ex- haustion should be avoided, so that regular brief exercises are preferable to attempts at long periods of activity. At home relatives can be instructed to carry out exercises daily over the full range of movement. When wrist-drop develops, a splint may help maintain grip; foot braces should be obtained only if the disease appears to be following a relatively benign course. It is unusual for patients to develop bedsores unless there is gross neglect ${ }^{8}$ - possibly because sensation and bladder control remain intact-but proper nursing care is still essential. Cramp is common and may be exacerbated by overactivity. Sometimes this can be relieved by heat or massage, but muscle relaxants such as baclofen or diazepam are often necessary, though the patient may dislike them if they also cause increased flaccidity. In such circumstances, quinidine, phenytoin, or calcium should be tried.

Progressive bulbar palsy results in gross disturbance of speech. At first the voice tires easily and becomes rasping and, later, monotonous and nasal. Eventually the patient can make only inarticulate noises. Letter and word cards may help, but a specially adapted electric typewriter allows greater freedom of expression and reduces the psychological burden that accompanies anarthria. A few exceptional patients have communicated by blinking in morse code or by shining a light attached to their foreheads on phrases on a screen placed in front of them. ${ }^{9}$

At first difficulties in swallowing are encountered with liquids, later with solids. As dysphagia increases the patient may need much help with eating to avoid aspiration. Though the tongue and lips may be appreciably affected, the oropharynx frequently continues to function relatively normally, so that the patient can swallow food more readily if it is placed on a spoon and deposited at the back of the mouth. ${ }^{2}$ In undernourished patients $15 \mathrm{mg}$ of neostigmine bromide by mouth 30 to 45 minutes before meals may temporarily improve food intake. Cricopharyngeal myotomy and cervical oesophagostomy, though recommended in certain patients by Smith and Norris, ${ }^{6}$ are not generally appropriate; nasogastric tubes should also be avoided. If sialorrhoea (drooling) is a problem anticholinergic drugs such as belladonna, propantheline, or amitriptyline should be prescribed. If the problem seems intractable transtympanic neurectomy under local anaesthesia or irradiation of the salivary glands should be considered. ${ }^{10}$

Sexual relationships may present problems, particularly in younger men. Potency is commonly retained even when much of the power in skeletal muscles has been lost. ${ }^{11}$ Given the opportunity, patients reveal a great deal of tension and anxiety on this score. If marital relations are to be maintained, it needs great mutual understanding between the patient and his wife, and it is often helpful for them to be able to talk to a doctor about the problems.

As the patient's disabilities increase frustration may lead to anger and anxiety compounded by depression. Both rage and tears must not only be expected but also accepted by the family and those in attendance. This commonly throws an increasingly intolerable strain on the wife and family if the patient is at home, and temporary or permanent admission to hospital may become necessary. Depression is best combated by maintaining real interest in the patient's life and by encouraging all possible expressions of his attitudes and concerns. If non-pharmacological measures fail to control these symptoms antidepressives or tranquillisers should be tried, though these do not always help.

Terminally, patients are usually bedridden. Opiates in small regular doses (for example, diamorphine and cocaine elixir (BPC), $2.5 \mathrm{mg}$ four-hourly) are often necessary to 
suppress ineffective attempts to cough and to relieve general distress. Tolerance is not a problem, and it is rarely necessary to increase the dose. Such a regimen reduces the need for suction of pharyngeal and tracheal secretions. It is a time when support and companionship are of paramount importance. Though the doctor may feel powerless in the face of death, his continued attendance (indicating that he will stand by the patient no matter what happens) is of inestimable value. After the first bad coughing or choking attack the patient will usually need carefully expressed reassurance that he will not be left to die alone or choke to death on his own secretions. Death generally occurs as a result of varying combinations of. aspiration pneumonitis, hypostatic bronchopneumonia, and carbon-dioxide narcosis, and both the family and nurses may need to have the inappropriateness of antibiotic treatment explained.

1 Walshe, F, and Walshe, J, Diseases of the Nervous System, 11th edn, p 256. Edinburgh, Livingstone, 1970.

2 Mulder, D W, Modern Treatment, 1966, 3, 243.

3 Norris, F H, et al, Neurology, 1974, 24, 721.

4 Mulder, D W, and Espinosa, in Motor Neuron Diseases, eds F H Norris and L T Kurland, p 12. New York, Grune and Stratton, 1969.

5 British Medical fournal, 1976, 1, 1422.

6 Smith, R A, and Norris, F H, fournal of the American Medical Association, 1975, 234, 715 .

7 British Medical fournal, 1971, 2, 40.

${ }^{8}$ Furukawa, T, and Toyokura, Y, Lancet, 1976, 1, 862.

- Adams, M R, Fournal of Speech and Hearing Disorders, 1966, 31, 274.

10 Goode, R L, and Smith, R A, Laryngoscope, 1970, 80, 1078.

11 Jokelainen, M, and Palo, J, Lancet, 1976, 1, 1246.

\section{Beyond Calais}

Doctors whose native tongue is English find it difficult enough to write good medical articles, and for English translators of foreign language texts and foreigners writing English articles the difficulties are even greater. Professor Peter Newmark ${ }^{1}$ has recently given some tips to translators: translate the title last unless it clearly names the subject of the article; read the bibliography early on-English titles should give clues about the key words being used in the text; don't use a bilingual or multilingual dictionary as the only authority, because they have so many superfluous words; and read through the whole article before starting, during translation, and on completion.

Direct translation is often impossible. "Chronic bronchitis," and "peptic ulcer," for instance, have quite different meanings in English, French, and German. Eponyms such as Pott's disease complicate matters, as several nations often claim the same test, theory, or syndrome for their own compatriots. An example is Graves's disease, which in French becomes "la maladie de Basedow," in Italian "la malattia di Flaja," and in German "Glotzaugenkrankheit." Elsevier's Medical Dictionary gives 42 different terms in five languages for hyperthyroidism. And what do you do about diseases with more than one name in English: do you choose mumps or epidemic parotitis, measles or morbilli ? Drugs, of course, are marketed under different trade names in different countries and their names always have to be checked. Fortunately English medical style is simpler than French or German and tends to use words in everyday use. Even so, Professor Newmark points out that it is not as simple as all that: in French and German, for example, there is no word for knuckle; in French, none for shin; and the Russians do not distinguish between hand and arm.
In addition to medical terms, the translator also has to convey to the reader the same meaning and emotional impression that he imagines (clearly he cannot know for certain) the original writer produced on his own reader. He also has to remove barbarities of style; clarify and abridge; check for inaccuracies and misspellings; and, in general, make the article readable and interesting. Nevertheless, there can be no iron rule about language. There is much more uniformity of style among journals in Britain than on the Continent: they are less flowery than the French (and presumably, because of this, compress more information into a smaller space) and less academic than the Germans. English sentences usually have objects as subjects, in most main clauses they use passive verbs, and the stress is on verbal nouns rather than verbs and nouns. Unlike other technical languages they try to avoid the multiple noun compound, though these do occasionally slip in and one may find sextuple noun compounds such as "baseline cadaver-kidney transplant survival rate."

The task facing a medical translator is formidable, but no greater than that of the brave foreigner who tries to write his medical article in English (but how well many of them succeed). His general English will have to be idiomatic and his vocabulary extensive and up to date, but there are many pitfalls for the unwary. ${ }^{2}$ In French, for instance, the groin is l'aine and le groin means snout of a pig or boar; our anthrax is le charbon, but their l'anthrax means a cluster of boils; il s'abuse means he is mistaken; the pelvis is le bassin; and un éditeur is a publisher (an editor being un rédacteur). Whimster's ${ }^{3}$ experience with Finnish and other Nordic authors has provided many examples of charming non-existent words creeping in, such as "subfebrility," "unprecise," and "fallacity," and obsolete words like "semiology" (for "symptomatology") and "ulcus ventriculi."

American English, too, often needs translating, as the recently published The Language of Medicine $e^{4}$ shows, though similar faults are often found in articles by English authors. VD or ESR, for example, will be understood by most Englishmen, but American abbreviations such as WDWNWM c/o SOB (jargon for well-developed and well-nourished white male complaining of shortness of breath) are unlikely to be understood by Europeans. Their truncated forms of words may also lead to confusion-(electro)lytes, multip(ara), (electrocardio)gram, osteo(myelitis)-while their gobbledygook includes summarisation for summary, and osseous structures for bones.

Thoreau's plea to "simplify, simplify" remains the key to better medical writing, but there are other obstacles to clarity that are self-imposed. A universal uniformity of style in medical journals would help. We may have freed ourselves from the pretentious use of Latin and Greek (and no longer claim, like Gibbon "My English text is chaste, and all licentious passages are left in the decent obscurity of a learned language"), but we carry an ever-increasing burden of synonyms, eponyms, acronyms, and technical jargon. While these may be essential in describing methods and results, they should be kept to a minimum in descriptive writing. The single common characteristic of great medical writers from Hippocrates onwards has been that they are easy to read. If it's hard going, it's almost always second class.

\footnotetext{
1 Newmark, P P, The Incorporated Linguist, 1976, 15, 41-7, 63-7.

2 Farfor, J A, and Benhamou, J P, Lancet, 6 October to 3 November 1973, 788, 840,901, 959, 1018.

3 Whimster, W F, in Lock, S, Thorne's Better Medical Writing, 2nd edn, London, Pitman Medical (in press)

4 Dirckx, J H, The Language of Medicine. Maryland, Harper \& Row, 1976.
} 